\title{
Renovando, Uma Vez Mais
}

$\mathrm{O}$ ANO DE 2007, quando os ABE\&M atingem o volume 51, está se caracterizando por sucessivas mudanças. Além do novo aspecto visual da revista, estamos vivenciando uma gradativa mudança do corpo editorial.

Considero um grande privilégio assumir a editoria da revista ABE\&M, e quero estender a minha imensa satisfação em dar as boas vindas aos novos co-editores, Dr. Evandro S. Portes e Dr. Magnus R. Dias da Silva que, juntamente com a Dra. Sandra R.G. Ferrreira, integrarão o corpo editorial da revista a partir deste mês.

O Dr. André Reis, que atuou ativamente como co-editor até o mês de março, solicitou o seu desligamento devido a outros afazeres profissionais. Um dos trabalhos marcantes do Dr. André nos ABE\&M está consolidado na edição especial passada, volume 51/2, "Diabetes Mellitus e Doença Cardiovascular".

Os ABE\&M, como os membros da SBEM bem o sabem, atingiram uma posição de destaque dentre as revistas científicas brasileiras, impulsionado pela brilhante condução do Dr. Claudio Kater como editor-chefe por mais de uma década. O trabalho que agora assumimos deverá ser menos árduo do que o foi para os que nos antecederam, mas vem condicionado à grande responsabilidade em mantermos as conquistas e evoluirmos ainda mais. Neste contexto, a recém-formada equipe assume a responsabilidade editorial dos ABE\&M com o mesmo entusiasmo dos antecessores que conduziram a revista até o presente patamar.

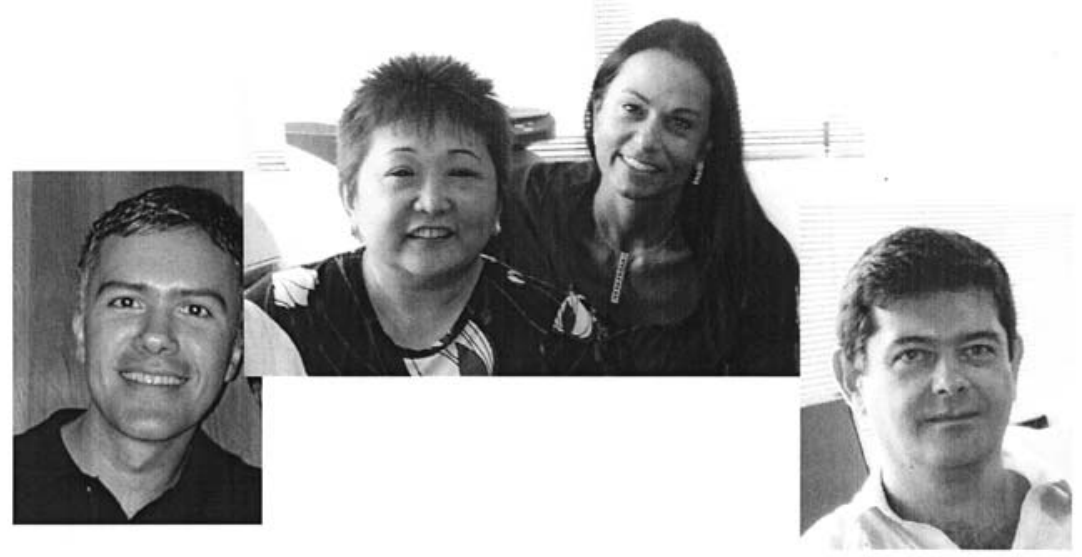

Composição do novo Conselho Editorial dos ABE\&M para a gestão 2007-2008: (E para a D) Magnus R. Dias da Silva, Edna T. Kimura, Sandra R.G. Ferreira e Evandro S. Portes

\section{editorial}

EDNA T. KIMURA

Professora Associada, Instituto de Ciências Biomédicas, Universidade de São Paulo (ICB-USP), São Paulo, SP, Brasil. Editora-chefe, ABE\&M 
Nas últimas duas décadas temos observado uma revolução na compreensão dos mecanismos das doenças, apoiada nos avanços da genética, biologia molecular e genômica. Este avanço tem modificado conceitos de patogênese e de classificação das doenças, assim como os critérios de diagnóstico, prognóstico e de novas condutas terapêuticas. A endocrinologia brasileira tem contribuído de maneira ímpar neste momento científico.

Pelo crescente aumento do número de artigos científicos submetidos e publicados, acreditamos que os ABE\&M têm cumprido plenamente a missão de divulgação do trabalho cientifico nacional; no entanto, queremos, também, ser a revista que os membros da SBEM, nossos principais leitores, almejam.

Observa-se que, apesar do canal aberto que os editores que nos precederam sempre deixaram, temos um feedback muito tímido quanto aos anseios dos leitores em relação ao conteúdo dos ABE\&M. Enfatizamos a importância deste diálogo e queremos abrir uma vez mais o nosso contato pelo email abem@uol.com.br. Sugestões, críticas e comentários serão sempre bem-vindos!

Continuaremos atentos à constante melhoria da qualidade dos artigos, mas também queremos aproximar nossos ABE\&M ao anseio de nossa Sociedade. 